\title{
Animals, Mimesis, and the Origin of Language
}

\author{
Kári DRISCOLL \\ One imitates only if one fails, when one fails. \\ Gilles Deleuze, Félix Guattari, \\ A Thousand Plateaus
}

\section{Prelude: Forest Murmurs}

Reclining under a linden tree in the forest in Act II of Richard Wagner's opera Siegfried, the titular hero is struck by the sound of a bird singing above him. "Du holdes Vöglein! / Dich hört' ich noch nie," he exclaims. ${ }^{1}$ Having just been musing on the identity of his mother, whom he never knew, Siegfried interprets the interruption as a message of some sort: "Verstünd' ich sein süßes Stammeln!/Gewiß sagt' es mir 'was,/vielleicht von der lieben Mutter?” He cannot understand the bird's song, but it simply must be saying something to him; if only he could learn its language somehow.

(Er sinnt nach. Sein Blick fällt auf ein Rohrgebüsch unweit der Linde.)

Hei! ich versuch's,

sing' ihm nach:

auf dem Rohr tön' ich ihm ähnlich!

Entrath' ich der Worte,

achte der Weise,

sing' ich so seine Sprache,

versteh' ich wohl auch, was es spricht.

(Er hat sich mit dem Schwerte ein Rohr abgeschnitten, und schnitzt sich eine Pfeife draus. $)^{2}$

Siegfried's reasoning here presupposes a direct correlation between imitation

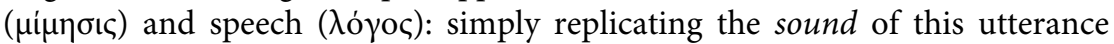
will automatically provide access to the meaning of that utterance. According to such a mimetic model of language, the signifier and the signified are one and the same. Readers familiar with the opera will already know the outcome of Siegfried's attempt to imitate the forest bird, but for the moment suffice it

1 Richard Wagner: “Zweiter Tag: Siegfried.” In: Gesammelte Schriften und Dichtungen. Volks-Ausgabe, vol. 6. Leipzig 1871, p. 134.

2 Ibid., p. 134-135. 
to say that this scene is remarkable not only as a turning point in the opera, and hence in Siegfried's quest to reclaim his heroic destiny, but also because it brings together a series of interrelated questions concerning the relationship between language and imitation, the distinction between mimesis and mimicry, and ultimately, of course, the difference between humanity and animality. In what follows, I will take the scene with the forest bird as a starting point for an exploration of these and related questions, particularly with reference to Enlightenment theories of the origin of language, in which the figure of mimesis is itself a leitmotif.

In order to imitate the bird's song, Siegfried fashions himself an instrument out of a reed: he refashions nature in order to imitate nature-nature becomes 'second nature'. The scene with the bird is thus already a rupture with the natural world, and as such forms part of a trajectory from nature/animality to culture/humanity that can be traced back to the very beginning of the opera. When we first encounter Siegfried, it is in the company of a large brown bear that he has brought back from the forest in order to torment his adoptive parent, Mime. Siegfried does not yet know that he is adopted, but he has begun to suspect that he does not belong, and feels more at home in nature among the forest animals. Indeed, it is by observing the natural order of things in the forest that he has come to the conclusion that something is fundamentally amiss at home. Having sent the bear on his way, Siegfried begins to question Mime about the disparity between his domestic situation and that of his animal friends. He reminds Mime how he had once explained to Siegfried that the birds singing to each other "so selig im Lenz" were "Männchen und Weibchen."3 Even wild foxes and wolves seem to have a mate with whom to raise their offspring, but "Wo hast du nun, Mime,/dein minniges Weibchen, / daß ich es Mutter nenne?" Mime is terribly vexed by the question: "Was ist dir, Thor?/Ach, bist du dumm! / Bist doch weder Vogel noch Fuchs?"4 Mime insists that the boy believe what he is told, namely that he is both Siegfried's father and his mother. With Mime claiming absolute authority for himself, Siegfried now once more appeals to the state of nature in order to abrogate Mime's paternal status entirely:

\section{SIEGFRIED}

Das lügst du, garstiger Gauch!-

Wie die Jungen den Alten gleichen,

das hab' ich mir glücklich erseh'n.

Nun kam ich zum klaren Bach:

da erspäht' ich die Bäum'

und Thier' im Spiegel;

$3 \quad$ Ibid., p. 92.

4 Ibid., p. 93. 


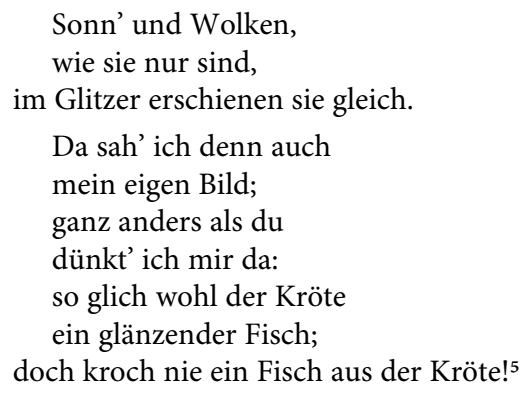

Siegfried's experience of seeing his own face reflected in the stream precipitates a mental reflection on identity and difference, and specifically on the question of heredity and physiognomy. Moreover, this 'mirror scene' is itself mirrored rhetorically in the chiasmus establishing the dissimilarity of the beautiful, shining fish to the slimy, amphibious toad. It is clear enough who is who, and as Marc Weiner observes, this juxtaposition, which is at work from the beginning of Das Rheingold to Mime's death at the end of Act 2 of Siegfried, in turn mobilises a set of racial stereotypes, that to a contemporary audience would clearly identify Mime, and the entire dwarf race of the Nibelungen with the Jews. ${ }^{6}$ This is significant specifically with regard to the economy of mimesis and mimicry at work in the opera and in Wagner's theory of art. I will return to this issue later.

Just as Siegfried sings "mein eigen Bild," a distinctive leitmotif may be heard in the background; later, in the forest, the theme is played again, always in response to a reaffirmation of Siegfried's heritage and identity as a Wälsung. In other words, he has come one step closer to subjecthood; to fulfilling his destiny and becoming, as it were, himself. The formation of identity is enacted here through the establishment of difference: where the comparison with birds and foxes fell short with regard to Siegfried himself, he is able to extrapolate the correlation between animals and their young in order to prove that he and Mime cannot be related. Nevertheless, this act of liberation has cost him the allegiance of his forest friends. "Alle Thiere sind/mir teurer als du" 7 he impetuously informs Mime, yet it is now clear that he has just as little in common with them as he does with his adoptive father.

Mime is eventually forced to admit that Siegfried's dying mother, Sieglinde, had entrusted him as a newborn baby to his care. As he gradually reveals this information, he repeats as a refrain the litany of sacrifices he has made for young

\footnotetext{
$5 \quad$ Ibid.

6 See Marc A. Weiner: Richard Wagner and the Anti-Semitic Imagination. Lincoln NE 1995, p. 91.

7 Wagner: "Siegfried" (footnote 1,) p. 91.
} 
Siegfried's sake, raising him as his own, clothing, feeding, and caring for the boy. Siegfried is having none of it:

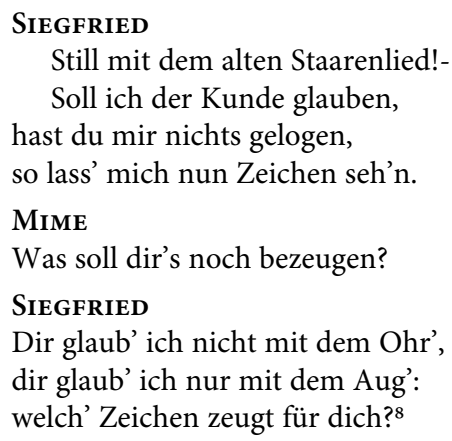

Siegfried is tired of hearing the same old song and now demands actual, visual evidence. Even the audience is bored, as this is in fact the second time we have heard Mime's story: he first sings his rearing song when Siegfried, returning from the forest, refuses to eat the food the former has prepared for him. After all he's done for him, Mime complains, this is his reward: "daß der hastige Knabe/ mich quält und haßt!"9 Siegfried replies that Mime may indeed have taught him a thing or two, but the one thing he could never learn was how to love him. Try as he might, the mere aspect of the dwarf is enough to put him off for good: "Seh' ich dich erst/mit den Augen zu, / zu übel erkenn' ich/was alles du thu'st."10 Siegfried now insists that he will believe Mime with his eyes, not his ears-his experience with his mirror image in the forest stream has taught him to believe what he sees, not what he's told. Moreover, Siegfried now refers to Mime's rearing song as "das alte Staarenlied": on the one hand, this aligns Mime with the birds of the forest, as fundamentally different from Siegfried himself. On the other hand, starlings are famous mimics, and so the "Staarenlied" also implies dissemblance and the deceptive potential of language, which belies the physical reality of the speaker. Thus Siegfried demands visual proof, and Mime has no other choice but to present the shattered pieces of Siegmund's sword Nothung - and in the background we hear, overlaid with the staccato forging motif, the familiar strains of the Siegfried the Wälsung theme.

At once, the broken sword becomes a symbol for Siegfried's interrupted heritage. This is what Mime has been hiding from him; this is the key to his true identity. He commands Mime to forge it anew for him and storms off into the forest. Mime, however, is left cursing his luck: try as he might, he cannot

\footnotetext{
$8 \quad$ Ibid., p. 97.

9 Ibid., p. 90.

10 Ibid., p. 91.
} 
re-forge the sword. In fact Siegfried is the only one who can re-forge it, because he alone has never experienced fear. In other words, it is precisely Siegfried's ignorance that sets him apart. He is still learning. Moreover, he is not learning through Mime's teaching: when Siegfried asked his adoptive father how it is that he always returns home despite the fact that he can't abide him, Mime responded that it just went to show "wie lieb ich am Herzen dir lieg," to which Siegfried responds:

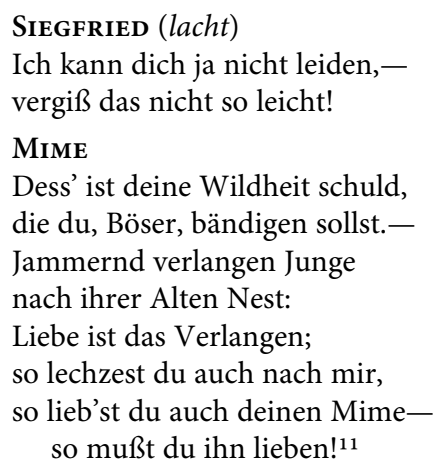

This explanation does not satisfy Siegfried; he is not ready to tame his wildness, and he will not be tamed by Mime's admonitions. Instead, the way she-wolves and vixens protected their young from his advances showed him "wohl/was Liebe sei."12 It is in this context that he asks Mime where his "minniges Weibchen" is, and Mime's paternity begins to unravel. Once Nothung has been re-forged, Siegfried is once again in contact with his true heritage; but he is not yet entirely free of Mime's influence. In the hopes of laying his hands on the Ring, Mime leads Siegfried deep into the forest to Fafner's cave under the pretext of teaching Siegfried a valuable lesson: the meaning of fear.

And so we are back to where we started, with Siegfried alone with the forest bird, just about to play the first notes on his makeshift reed pipe. And that is where we will leave him for the moment, and instead go even further back and explore the philosophical foundations and implications of this encounter.

\section{Similarity and Difference}

Siegfried's reaction to the bird's song is that of one sentient being responding to another. It is an acknowledgement of similarity followed by the desire to communicate. Jean-Jacques Rousseau, in his Essay on the Origin of Languages (1781,) posits this moment of recognition as the primus motor for the development of language:

11 Ibid., p. 92.

12 Ibid., p. 93. 
As soon as one man was recognized by another as a sentient, thinking Being, similar to himself, the desire or the need to communicate to him his sentiments and thoughts made him seek the means to do so. These means can be only be drawn from the senses, the only instruments by which one man can act upon another. ${ }^{13}$

The ability to recognise similarity implies the establishment of difference. The first two sentences of the Essay make this doubly clear: "Speech [parole] differentiates man from the other animals: language [langage] differentiates one nation from the other; where a man is from is known only once he has spoken." 14 Language is here subordinate to speech in the hierarchy of distinctions; "speech, being the first social institution, owes its form only to natural causes." Yet contrary to what a number of Rousseau's contemporaries and predecessors, such as Descartes, Condillac, or La Mettrie had claimed, these natural causes do not amount to the specific arrangement or constitution of the speech organs. "Animals have a physical organization more than sufficient for such communication," Rousseau affirms, "and none of them has ever made this use of it."

Here, it seems to me, is a most characteristic difference. Those who, among them, work and live in common, such as Beavers, ants, and bees, have some natural language [langage] in order to communicate amongst themselves-I raise no doubt about it. There is even reason to believe that the language of Beavers and that of ants are in gesture and speak only to the eyes. Be that as it may, precisely because all such languages are natural, they are not acquired; the animals that speak them do so from birth, they all possess them, and everywhere the same one; they do not change them, nor do they make the slightest progress in them. Conventional language belongs only to man. That is why man makes progress, whether for good or bad, and why the animals do not at all. This single distinction seems to lead a long way. ${ }^{15}$

For Rousseau, this is indeed the distinction above all others. In the Second Discourse he makes a similar point, insisting that "Every animal has ideas, since it has senses," 16 and so it is "not so much the understanding that constitutes the specific difference between man and the other animals, as it is his property of

13 Jean-Jacques Rousseau: "Essay on the Origin of Languages: In Which Melody and Musical Imitation are Treated." In: John T. Scott (ed.): On Philosophy, Morality, and Religion. Hanover NH 2007, p. 103 (trans. John T. Scott.)

14 Ibid.

15 Ibid., p. 106.

16 Jean-Jacques Rousseau: "Discourse on the Origin and the Foundations of Inequality among Men." In: The Discourses and Other Early Political Writings. Cambridge 1997, p. 140 (ed. and trans. Victor Gourevitch.) 
being a free agent."17 It is precisely this freedom which detaches mankind from nature. Moreover, it is clear from Rousseau's writings that even in the state of nature, man was free, and in fact, was much happier in that state than he is in society. ${ }^{18}$ It is worth noting that in the preface to the Second Discourse, Rousseau makes an explicit distinction between 'sentient' and 'rational' beings with regard to this similarity:

Indeed, it would seem that if I am obliged not to harm another being like myself, this is so less because it is a rational being than because it is a sentient being; a quality which, since it is common to beast and man, must at least give the beast the right not to be needlessly maltreated by man. ${ }^{19}$

Although it would be misleading to suggest that Rousseau was a proponent of what we would today refer to as animal rights, it is nevertheless important to emphasise that he does not draw an a priori distinction between man and animal based on reason: "Regardless of what the Moralists may say about it, the human understanding owes much to the Passions which, as is commonly admitted, also owe much to it: It is by their activity that our reason perfects itself." 20 As we shall see, it is the trait of perfectibility which for Rousseau is all-important in distinguishing man from animal. Reason is a product of the passions, which we share with all sentient beings, and the circularity of the above passage points to the difficulty in accounting for the specific differentiating factor.

Rousseau is hard pressed to describe what might have prompted the first men to speak at all. He superficially endorses Condillac's account of the origin of language, but then immediately points out that the latter "assumed what I question, namely some sort of society already established among the inventors of language" 21 and so he proceeds to offer a number of conjectures of his own on the origin of language. At every turn, however, he is forced to admit that he cannot offer a coherent explanation for it, and even after glossing over various fundamental stages- "Let us suppose this first difficulty overcome"22-he arrives back where he started:

As for myself, frightened by the increasing difficulties, and convinced of the almost demonstrated impossibility that Languages could have arisen and been established by purely human means, I leave to anyone who wishes to undertake it the discussion of this difficult Problem: which is the more necessary, an already united Society for the institution of

17 Ibid., p. 141.

18 Ibid., p. 150.

19 Ibid., p. 128.

20 Ibid., p. 142

21 Ibid., p. 145.

22 Ibid., p. 146. 
Languages, or already invented Languages for the establishment of Society?23

Frustrated by the seeming impossibility of a human invention of language, Rousseau goes back to his initial premise of human freedom and perfectibility. Because man has no instinct of his own, he is more adaptable than other animals, even though initially he is the least adapted to his surroundings. "Men, dispersed among [the animals], observe, imitate their industry, and so raise themselves to the level of the Beasts' instinct." ${ }^{24}$ In other words, man is at first not even on par with the other animals, and, through imitation, must raise himself up to their level. This capacity, however, allows him ultimately to rise still further and assume the position of dominance over all nature that he enjoys today.

But perfectibility also carries with it the possibility of regression: "Why is man alone liable to become imbecile?" Rousseau asks.

Is it not that he thus returns to his primitive state and that, whereas the Beast, which has acquired nothing and also has nothing to lose, always keeps its instinct, man again losing through old age and other accidents all that his perfectibility had made him acquire, thus relapses lower than the Beast itself?25

From here it only requires a small step to realise that this trait of perfectibility in fact describes a fundamental lack or deficiency in the human animal, which must be supplemented through language. This "dangerous supplement" is ultimately the cause of the inexorable degeneration of human society which Rousseau diagnoses in his Essay and in the Second Discourse. It is dangerous precisely because it "breaks with Nature," 26 which is defined as innocent and perfect plenitude, and hence does not require a supplement. The supplement of

23 Ibid., p. 149.

24 Ibid., p. 134.

25 Ibid., p. 141. Rousseau is by no means the first to observe this potential for deficiency in man. As Daniel Heller-Roazen notes, the ninth century Muslim scholar Al-Jāhiz considered mankind's defining characteristic in relation to other animals to be our ability to fail or to do less. Thus, birds for example sing "with unfailing melodic and metrical exactitude, pouring forth sounds that seem as if 'prepared for modulation and harmony, obeying prosodic and rhythmic laws.' They cannot do otherwise. If human beings, by contrast, can sing any song at all, they can, according to Al-Jāhiz, always also sing an easier, simpler, and lesser one. They can also sing out of tune and out of time, distorting the composition they aim to execute; and, finally, they can always also fail to sing altogether." Daniel Heller-Roazen: Echolalias: On the Forgetting of Language. New York 2005, p. 131-2.

26 See Jacques Derrida: Of Grammatology. Baltimore 1997, p. 151 (trans. Gayatri Chakravorty Spivak.) 
language introduces difference into the equation, disrupting the original harmony that was (supposedly) there before. Man, in Aristotle's famous definition, is the

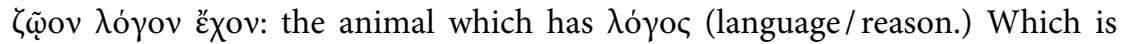
to say, even here language is coded as supplemental, an addition as marker of difference. Because of this supplement, man is the animal that is not an

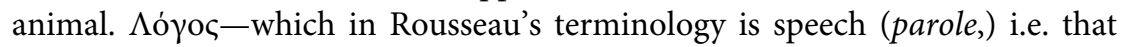
which separates mankind from animals-substitutes for the inarticulate voice of nature ( $\varphi \omega v \eta \dot{n}$.) But once this substitution has taken place, there is no turning back. One cannot simply subtract $\lambda$ ó $\gamma$ oc from the equation and hope to be left with the $\zeta \tilde{\omega}$ ov $\alpha$ - $\lambda$ ó $\gamma$ ov, the animal without $\lambda$ ó $\gamma o \varsigma$, which is Aristotle's term for all other non-human animals. A human, stripped of the faculty of speech (and, by implication, rational thought) is either a sub-human imbecile, lower than any brute, or else, as we shall see in a moment, a monstrous and unnatural hybrid, particularly if this lack is supplemented by means of a too-faithful imitation of the voice of nature.

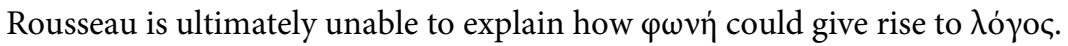
In all other respects, humans compensated for their lack of natural instincts by imitating the animals around them. By implication then, human language must also have arisen through such animal mimesis, but if human language arose naturally, how is it possible that humans alone have developed the faculty of speech? It is this impasse which makes an a priori supplemental distinction such as 'perfectibility' necessary, but it is 'dangerous' because, being a priori, it cannot point the way back to the originary presence and plenitude of Nature whence it must have sprung.

\section{Internal Bleating}

In his essay on the Conjectural Beginning of Human History (1786,) Immanuel Kant joins the ranks of Enlightenment philosophers who have attributed the emergence of human language to a primordial mimetic appropriation of an animal cry. Man, having an inherent need to make his existence known to the outside world, but lacking an innate means of doing so, imitates the sounds made by his fellow creatures, transforming these inarticulate sounds into words and concepts. These onomatopoeia then serve as names to designate the individual animals that produced the sounds in the first place. ${ }^{27}$ Certainly, this is a inadequate and problematic aetiology, but the direct progression from animal sound, via human imitation, to taxonomic designation which it describes is highly instructive, as it shows the human need for self-assertion-do animals

27 See Immanuel Kant: "Muthmaßlicher Anfang der Menschengeschichte." In: Sämmtliche kleine Schriften, nach der Zeitfolge geordnet, vol. 3. Königsberg 1797, p. 250. 
feel a similar need? What motivates them to bark and bleat and whinny and meow? Kant does not ponder these questions-when combined with the mimetic faculty, almost automatically gives rise to a desire to order and classify the world and its creatures. But this still does not explain how such mimesis could give rise to language in the first place. For this, we must have recourse to another concept which Kant elsewhere explicitly opposes to imitation, namely, genius.

"Darinn ist jedermann einig, daß Genie dem Nachahmungsgeiste gänzlich entgegen zu setzen sey," writes Kant in $\$ 47$ of his Critique of Judgment. “Da nun Lernen nichts als Nachahmen ist, so kann die größte Fähigkeit, Gelehrigkeit (Capacität) als Gelehrigkeit doch nicht für Genie gelten." 28 That is to say, genius is that which can neither be taught nor acquired through repetition and imitation. Genius cannot be derived or abstracted from pre-existing rules or laws, but rather constitutes the spirit of originality and innovation. Genius, in Kant's definition, is a talent whose first characteristic is originality. Secondly, it must be exemplary, i.e. not derived from a prior original, but rather serve as a model for the future. Thirdly, genius is natural, and it is impossible to give a scientific or rational account of how it generates its products, which means that "der Urheber eines Products, welches er seinem Genie verdankt, selbst nicht weiß, wie sich in ihm die Ideen dazu herbey finden." ${ }^{29}$ Kant's notion of genius serves primarily as a means of explaining how art-specifically good art (schöne Kunst) - may come into being, but it may equally serve to explain how man, by imitating animal sounds, was nonetheless able to produce human language, i.e. how $\varphi \omega v \eta \dot{~ c o u l d ~ g i v e ~ r i s e ~ t o ~ \lambda o ́ \gamma o c . ~}$

Genius is thus opposed to imitation (Nachahmung,) but imitation itself must be distinguished from mindless aping (Nachäffung,) which Kant illustrates by means of a student, who, failing to understand the working of genius, attempts to copy an original work, but makes the mistake of copying the errors in that original as well, "das, was das Genie als Missgestalt nur hat zulassen müssen, weil es sich, ohne die Idee zu schwächen, nicht wohl wegschaffen ließ." ${ }^{30}$ In other words, works of true genius contain errors and imperfections, which are nevertheless pardonable purely on account of the boldness with which they deviate from the established rules. This original swerve is the signature of genius, but it is not to be copied, lest the overly imitative student succumb to mere aping. One might therefore venture the hypothesis that it was the spirit of genius that allowed man to imitate the voice of nature, without copying the 'error' of animality.

28 Immanuel Kant: Critik der Urtheilskraft. Berlin 1790, p. 181.

29 Ibid., p. 180.

$30 \quad$ Ibid., p. 198. 
Needless to say, Kant's theory of genius depends no less on an a priori supplemental attribute than Rousseau's notion of perfectibility. Furthermore, the distinction between Nachahmung and Nachäffung is a precarious one, as it marks the boundary between 'human' and 'animal' mimesis, which as ever must be carefully patrolled. This, as we shall see, is played out in Johann Gottfried Herder's Abhandlung über den Ursprung der Sprache (1772.) In it he expressly repudiates both Condillac's and Rousseau's accounts, "da jener die Thiere zu Menschen, und dieser die Menschen zu Thieren machte." ${ }_{11}$ Condillac, in other words, presupposes a concept of language even in the state of nature (thereby elevating an animal to the level of man,) whereas Rousseau, who in the Second Discourse supposes that man's first language was the "cry of Nature," an expression of raw emotion, just like the language of all animals, and thus makes man an animal in the process. ${ }^{32}$ Having dismissed both these approaches as misguided, Herder sets about plumbing the depths of the animal-human divide. $\mathrm{He}$ too insists that reason alone cannot be regarded as the dividing line, at least not so long as reason is considered a supplement (Zugabe) to animal nature, and moreover as something that could ever be said to operate independently of the other human faculties ("Witz, Scharfsinn, Phantasie, Vernunft" etc.) ${ }^{33}$ The human soul (Seele) in indivisible, and if one piece were to be removed, the entire edifice of humanity would crumble:

Konnte ein Mensch je eine einzige Handlung thun, bei der er völlig wie ein Thier dachte: so ist er auch durchaus kein Mensch mehr, gar keiner menschlichen Handlung mehr fähig. War er einen einzigen Augenblick ohne Vernunft: so sähe ich nicht, wie er je in seinem Leben mit Vernunft denken könne: oder seine ganze Seele, die ganze Haushaltung seiner Natur ward geändert. ${ }^{34}$

The very constitution of man, in other words, precludes animality. Herder's opening sentence-"Schon als Thier hat der Mensch Sprache"35_must then

31 Johann Gottfried Herder: Abhandlung über den Ursprung der Sprache. Berlin 1772, p. 31.

32 Herder is referring only to the Second Discourse, not the Essay, which, despite possibly ante-dating the Discourse, was published only posthumously, in 1781, or ten years after Herder composed his treatise. Thus the references to the language of beavers and ants, as well as some of the other features discussed in the Essay could not be taken into account. Even so, Herder's objection that Rousseau's account reduces man to the status of an animal is not entirely well founded and somewhat disingenuous. Both philosophers effectively beg their question by presupposing a characteristic of man (be it perfectibility or Besonnenheit) that distinguishes him from the other animals even in a state of nature.

33 Johann Gottfried Herder (footnote 31,) p. 44.

34 Ibid., p. 45.

35 Ibid., p. 3. 
appear deliberately self-contradictory, since having language necessarily means not being an animal. Even as he goes on to equate the moaning and whimpering of a wounded animal to the painful howls of the hero Philoctetes, he is busy establishing the difference. If we choose to regard these "unmittelbaren Laute der Empfindung" as language, he concludes, then their origin is certainly quite natural, and not supernatural in the slightest. In fact, it is "offenbar thierisch: das Naturgesetz einer empfindsamen Machiene." 36 This seeming concession to Rousseau is anything but: Herder is in no way prepared to grant the status of language to these inarticulate grunts.

Herder then goes on to make an almost identical point to the one Rousseau makes in his Essay, namely that whereas all animals have some native language which is natural to them, human beings must acquire their languages. ${ }^{37}$ Man does not speak naturally, and does "wenig oder nichts durch völligen Instinkt, als Thier." 38 What little animal instinct is left, Herder promptly suppresses: "Ich nehme bei einem neugebohrnen Kinde das Geschrei seiner empfindsamen Maschine aus; sonst ists stumm." 39 The child thus exposed to the elements, naked and helpless, mercilessly stripped of its natural voice, would be unable to fend for itself, nor even to express its own deficiency! Such a state of affairs is unimaginable in nature: "Es müssen statt der Instinkte andre verborgne Kräfte in ihm schlafen!" 40

How are these latent powers awakened? Herder posits that instead of animal instincts, mankind is endowed with the innate faculty of reflection (Besonnenheit,) which is the specific capacity for making distinctions and thereby forming concepts, which in turn leads automatically to the creation of language: "Dies erste Merkmal der Besinnung war Wort der Seele! Mit ihm ist die menschliche Sprache erfunden!" 41 And what should this first distinguishing mark be but an animal, and more specifically, an animal sound? Herder has a sheep pass by his as-yet speechless human. In the first instance, it is man's

36 Ibid., p. 23.

37 This belated acquisition of language is of course both a symptom and a cause of the supplementarity of $\lambda$ ó $\gamma \circ \varsigma$, and points to a paradox in the very designation of

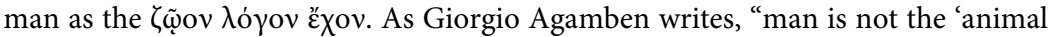
possessing language', but instead the animal deprived of language and obliged, therefore, to receive it from outside himself." Either way, the difference between

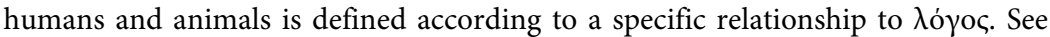
Giorgio Agamben: Infancy and History: The Destruction of Experience. London 1993, p. 57 (trans. Liz Heron.)

38 Herder (footnote 31 ,) p. 37.

39 Ibid.

$40 \quad$ Ibid., p. 38.

41 Ibid., p. 53. 
lack of predatory instinct which permits him to engage with the animal on a more abstract level. The sheep is apprehended as a cluster of adjectives-white, soft, woolly-yet it is the distinctive sound the sheep makes which creates the strongest impression on the man's soul, understood here as the ensemble of reflection and linguistic capability. The soul, in turn, translates this characteristic bleating sound into the name of this creature, quite without the man ever even needing to utter a word, or communicate this idea to another:

Käme er also auch nie in den Fall, einem andern Geschöpf diese Idee zu geben, und also dies Merkmal der Besinnung ihm mit den Lippen vorblöcken zu wollen, oder zu können; seine Seele hat gleichsam in ihrem Inwendigen geblöckt, da sie diesen Schall zum Erinnerungszeichen wählte, und wiedergeblöckt, da sie ihn [sic] daran erkannte - die Sprache ist erfunden! ebenso natürlich und dem Menschen nothwendig erfunden, als der Mensch ein Mensch war. ${ }^{42}$

Herder is quite emphatic in his insistence that human language is the product of acoustic stimuli from nature which are first isolated and labelled by the soul and then translated into words. The sheep bleats, man determines this to be the sheep's defining characteristic, and then, even if there is no one around to hear it, man's soul quietly bleats inwardly to itself. This is the birth of language.

This account stands in marked contrast to Kant's: the mimetic appropriation of the animal's sound as Herder describes it has nothing whatsoever to do with the need to communicate. Herder's man is alone with his sheep, and bleats inwardly. More importantly, for Herder's argument, language is such a fundamental prerequisite for being human that it would have been invented even if this solitary first man had never encountered another living creature. Far from emerging in response to the sheep, which would imply a form of communication and mimetic approximation to a non-human Other, language, Herder insists, is the "Einverständniß seiner Seele mit sich, und ein so nothwendiges Einverständniß, als der Mensch Mensch war." ${ }^{43}$ Rousseau's puzzlement about the social conditions of possibility for the emergence of language are completely beside the point, as far as Herder is concerned, since the human soul qua soul must necessarily always already have invented language for itself, "schon ohne Mund und Gesellschaft." ${ }^{4}$ Nevertheless, the strict demarcation of human and animal, which Herder is so careful to enforce, is undermined by the seemingly inadvertent grammatical contagion evident in the use of "ihn" instead of "es" in the passage cited above: "da sie [die Seele] ihn daran erkannte." Although Herder clearly means the sheep, it is nevertheless a

$42 \quad$ Ibid., p. 56.

43 Ibid., p. 58.

44 Ibid. 
telling slip, since it renders it unclear whether the human soul is recognising the sheep or the man as "das Blöckende." Indeed, at this precise moment, the epithet applies to both. But this ambiguity is intolerable to Herder, whose theory depends on the unmistakable and irreducible difference between the two. Such is the danger of mimesis. ${ }^{45}$

In order to avoid any such ambiguity, Herder is careful to distinguish imitation (Nachahmung) from mere aping (Nachäffung.) In the previous section he had already dismissed monkeys and parrots as mere imitators of human actions and speech: "Der Affe äffet immer nach, aber nachgeahmt hat er nie: Nie mit Besonnenheit zu sich gesprochen: 'das will ich nachahmen, um mein Geschlecht vollkommner zu machen!" 46 and later: "Papagei und Staar haben gnug menschliche Schälle gelernt; aber auch ein menschliches Wort gedacht?" 47 And just as the man who somehow managed to think like an animal would instantly cease to be a man, if ever an ape were to produce a Nachahmung and not just a mere Nachäffung, "denselben Augenblick war er kein Affe mehr!" 48 Having once thought like a man, the ape's constitution would be fundamentally altered, and he would have to create his own language in order to express it.

Despite its origin in external, animal sounds, Herder's first language is not only poetic, but autopoietic. That is to say, notwithstanding the seemingly mimetic interaction between the human and the sheep in his pastoral aetiology, the origin of language cannot, in Herder's account, lie in mimesis, in the imitation of something already found in nature: i.e. it cannot have its origin elsewhere. In fact, the invention of language is the inevitable result of the human soul's autoaffective communication. This is why Herder also rejects the ancient notion that mankind might have learnt to speak by imitating the birds, an idea implicitly espoused by Rousseau in the Essay. Each species of animal has its own idiomatic, natural language, which it speaks only for itself and to its own kin. Nightingales do not sing for human beings, and no human could ever have thought to invent language by imitating their trilling. Herder finds such an idea not just absurd but abhorrent: "Und was ists doch für ein Ungeheuer,

45 This pronominal confusion also occurs one page earlier, during the first hypothetical encounter with the sheep ("weil ihn [recte: es] sein Instinkt auf etwas anders wendet," ibid., p. 54.) Such cases of mistaken identity are prime examples of the sorts of 'accidents' Kelly Oliver identifies as evidence of the way Herder's and Rousseau's textual animals have an unpredictable and irrepressible tendency to "bite back." See Kelly Oliver: "Animal Pedagogy: The Origin of 'Man' in Rousseau and Herder," Culture, Theory and Critique 47:2 (2006,) p. 107-31.

47 Ibid., p. 70.

$48 \quad$ Ibid., p. 69. 
eine menschliche Nachtigall in einer Höhle, oder im Walde der Jagd?" 49 This human-nightingale hybrid that Herder conjures up is fundamentally unnatural and therefore inherently monstrous: language cannot, as Rousseau supposes, be the result of man's imitation of the other animals, because that would imply, or so Herder claims, that human language is nothing but a further development of animal sounds, which is impossible because nature is fixed and immutable. At the same time, Herder rejects the idea of language as divinely imbued, which would likewise place its origin outside the human. No: what sets humans apart from animals is not that they have language, but that they create their language themselves, and cannot do otherwise. Hence any man who successfully imitated the song of the birds would immediately cease to be a man. In order for humanity to persist, it is imperative that he fail.

\section{Interlude: "Das tönt nicht recht!"}

And so we return to our hero Siegfried, poised just where we left him with his makeshift reed pipe, about to replicate the bird's song in the hope of thereby learning its language. He calmly waits his turn before launching into his interlocution: “Es schweigt und lauscht: / so schwatz' ich denn los!”

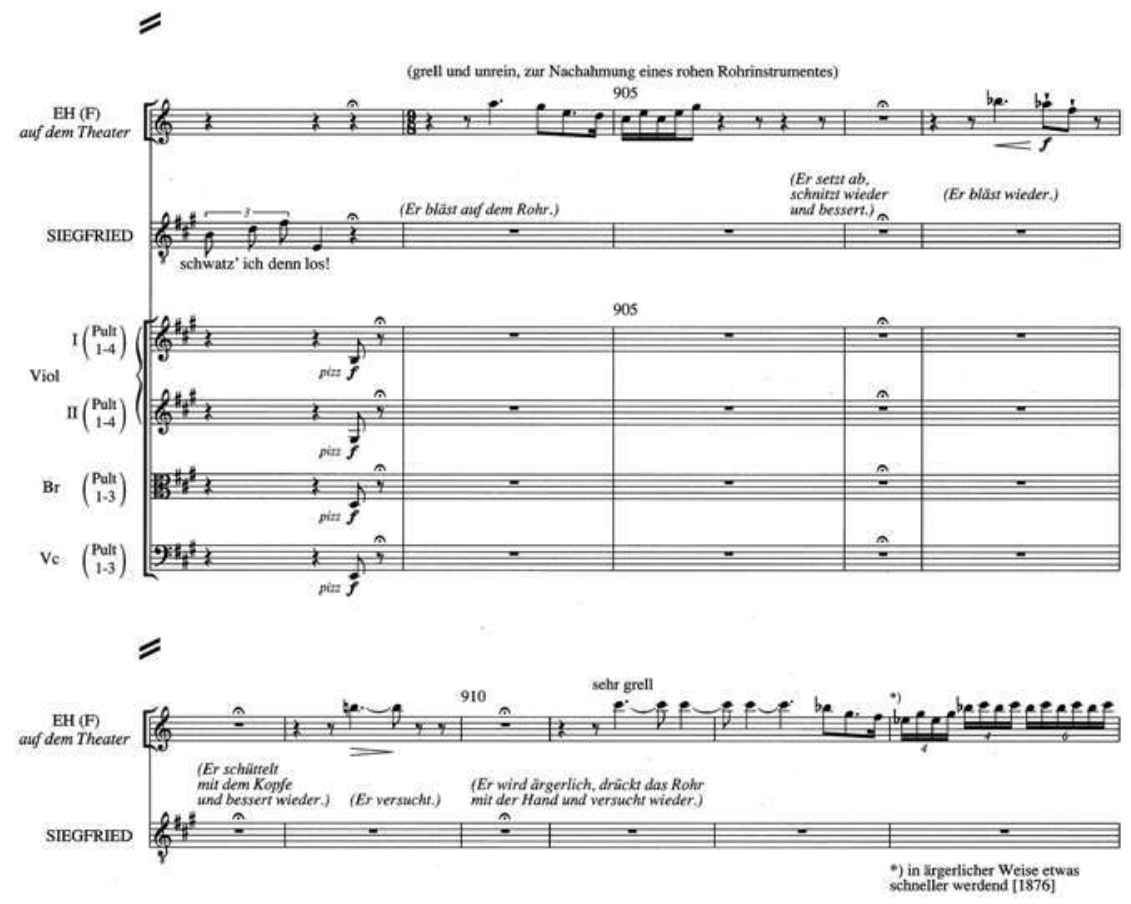

49 Ibid., p. 89. 
Finally, he gives up with a smile. "Das tönt nicht recht," he concedes, auf dem Rohre taugt die wonnige Weise mir nicht. Vöglein, mich dünkt, ich bleibe dumm: von dir lernt sich's nicht leicht! ${ }^{50}$

Siegfried cannot decipher the bird's language by replicating its song: indeed, he cannot even imitate it correctly. His 'instrument' is too 'raw' to reproduce the delicate melody sung by the bird. Moreover, the more he 'perfects' (bessert) his instrument, the less it sounds like the birdsong he is trying to imitate, until finally he abandons the project entirely and invites the bird instead to listen to a merry forest ditty he knows how to play on his horn. As he explains, he has played it before in the hopes of attracting a companion, but so far he's managed only to attract the occasional wolf or bear. "Nun will ich seh'n,/wen jetzt sie mir lockt: / ob das mir ein lieber Gesell?" 51

Far from enticing a playmate for young Siegfried, the sound of his horn awakens the slumbering giant Fafner, who has transformed himself into a monstrous dragon-like creature and lies there guarding his hoard. Siegfried, however, is unperturbed, and is even more delighted when it emerges that this creature speaks!

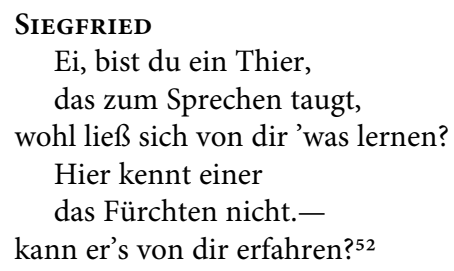

Fafner, no doubt accustomed to being feared by whomsoever approaches his lair, questions the boy's bravado. Siegfried replies that he doesn't know whether it's bravery or bravado ("Muth und Übermut - / was weiß ich!,") but if he doesn't teach him what fear is, he'll be sorry. Fafner, however, unaware of Siegfried's identity, has no interest in acting as this cocksure youth's teacher. A fight ensues, and Siegfried slays Fafner with the newly re-forged sword Nothung.

This encounter serves as a complement to the encounter with the bird, and both together provide a locus for Siegfried's further development on the road to becoming himself. The middle section of the merry Waldweise Siegfried plays

50 Richard Wagner: Sämtliche Werke, vol. 12.2: "Der Ring des Nibelungen. Ein Bühnenfestspiel für drei Tage und einen Vorabend. Zweiter Tag: Siegfried. WWV 86 C. Zweiter Aufzug." Mainz 2008, p. 127-8 (ed. Klaus Döge.)

51 Richard Wagner: "Siegfried" (footnote 1,) p. 135.

52 Ibid., p. 136. 
on his horn is actually a version of the Siegfried the Wälsung theme, and twice in Siegfried's exchange with Fafner this leitmotif reappears, in both instances as a response to the question of Siegfried's identity: "Viel weiß ich noch nicht,/ noch nicht auch wer ich bin" and again as the victor reveals his name to the vanquished: "Siegfried bin ich genannt." ${ }_{53}$ Upon hearing this name, Fafner, the last of the giants, dies without having taught Siegfried either the meaning of fear or the secrets of his heritage. "Zur Kunde taugt kein Todter," declares Siegfried bluntly.

Let us pause here for a moment and recapitulate the situation. Siegfried, beset by a growing sense of alienation from all that he previously had known, recognises in the song of an unfamiliar bird what he takes to be the voice of another sentient being, one that might be able to reveal something about his identity. The attempt at communication fails, however, when Siegfried is unable to imitate the bird's song on his pipe. Instead he plays a tune on his silver horn, a tune, moreover, which we have come to associate with his true identity as a Wälsung. Siegfried, in other words, to all intents and purposes abandons his sub-standard imitative instrument and instead 'performs' his own identity on his own instrument-the one which he has had all along.

Siegfried's failure is significant in another sense as well, which is relevant to the distinction between Nachahmung and Nachäffung discussed above. In Wagner's notorious anti-Semitic pamphlet, Das Judenthum in der Musik (1850, rev. 1869,) what marks Jewish music and art as inferior is precisely its overly imitative character. Even a highly educated and prodigiously talented composer like Felix Mendelssohn-Bartholdy, Wagner writes, was only able to imitate his predecessors Bach and Beethoven, the true heroes of German music, but could never produce Art of the kind that would have a truly profound effect "auf uns." ${ }^{54}$ Mendelssohn's compositions may be entertaining and varied, but they are not really 'deep' because, as Wagner puts it, while they adeptly copy the "how" of these masters, they cannot articulate the "what" which would be the true, necessary, and meaningful purport of the musical utterance. Jewish music, in Wagner's estimation, has no content, it does not convey any deeper meaning; it is only superficial appearance, it has no 'soul'. In this, Wagner's distinction between German and Jewish music recapitulates the central tenets of Cartesian dualism, placing the Jews among the animals, who can only react, mechanically, but never properly respond, and who therefore also never progress: like Herder's ape, in other words, their imitation is purely instinctual, and does not serve to perfect their race.

53 Ibid., p. 138-139.

54 Richard Wagner: Das Judenthum in der Musik. Leipzig 1869, p. 25. 
Indeed, the progress of German music, from Bach to Mozart to Beethoven (and, inevitably, to Wagner himself,) is explicitly likened to the progress of humanity out of a state of animality. In a somewhat forced parallelism, Wagner claims that "Die Sprache Bachs steht zur Sprache Mozarts und endlich Beethovens in dem Verhältnisse, wie die ägyptische Sphinx zur griechischen Menschenstatue: wie die Sphinx mit dem menschlichen Gesichte aus dem Thierleibe erst noch herausstrebt, so strebt Bachs edler Menschenkopf aus der Perücke hervor." 55 An analogous progression is evident in Siegfried, who at the beginning of the opera is perfectly savage and animalistic, but whose noble human face gradually emerges to transcend his base, animal origins-which, of course, turn out to have been illusory from the start: his divine lineage is beyond question, and his destiny already written in the stars. The Jews and their music, by contrast, lack the spiritual depth and human face to transcend mere mechanical form. Wagner compares their ability to mimic the great geniuses of the past to the mechanical ability of birds to parrot human speech, "aber ebenso ohne Ausdruck und wirkliche Empfindung, wie diese närrischen Vögel es thun." ${ }^{56}$ It is thus doubly significant that it should have been a dwarf who gave Siegfried the notion that one might learn to understand the language of birds simply by imitating their song. A successful imitation of the bird's song might have given the superficial impression that the imitator was actually 'speaking' the bird's language, whereas in fact it only copies the "how" and not the "what" of the utterance. In his failure to imitate the bird's song, therefore, Siegfried succeeds in distancing himself from the tellingly named $\mathrm{Mime}^{57}$ and the other dwarfs, and, by implication, from the degeneracy of Jewish imitations, to appear as an original genius and fulfil his destiny as the saviour of German music.

When Siegfried's merry Waldweise attracts the attention of another nearby creature, Siegfried still retains hope that it will be able to teach him what he needs to know, but instead he is forced to kill the speaking animal. This

55 Ibid., p. 26.

56 Ibid., p. 20.

57 The significance of Mime's name is emphatically reinforced by Wagner's pseudoDarwinian comments in an 1868 essay concerning the distinction between Idealism and Realism in art, which, in Wagner's terms, are characterized by Nachbildung and Nachahmung of nature, respectively (whereby Nachahmung corresponds to Herder's Nachäffung.) For Wagner, the relationship between realist, i.e. purely mimetic, art, and genuinely creative, poetic art is strictly analogous to the relationship between ape and man. The latter, whose Nachbildung of nature creates something new and profound and true, is embodied by the German Dichter; whereas the proponent of the former, whose art is nothing but a perfect (yet inferior) copy of nature is: "der Mime." See Richard Wagner: Deutsche Kunst und Deutsche Politik. Leipzig 1868, p. 53-56; cf. Weiner (footnote 6,) p. 88-90. 
sacrifice, ultimately, is more valuable in Siegfried's continuing progression than anything that Fafner might have told him. Having slain the dragon and drunk its blood, Siegfried is suddenly able to understand the speech of the forest bird. Yet this is an entirely different sort of communication than he had originally been after. Siegfried emerges the triumphant hero to take possession of the Ring. No longer will he debase himself trying to sound like a bird: from now on Nature must speak his language, or not at all. Thus Siegfried's slaying of the dragon may be seen as a foundational sacrificial rite of passage, whereby the human subject emerges, as it were, from the blood of the animal. It is even more significant that Fafner should be "ein Thier / das zum Sprechen taugt," for, as we have seen, man explicitly asserts his dominance by denying the faculty of speech to other animals. "Zur Kunde taugt kein Todter": the speaking animal must be slain in order that human speech be the only speech there is.

\section{Ecce Homo}

Although Herder dismisses an animal origin for human language, he does, like Rousseau in his Essay, accept that it was initially more poetry than prose, and more song than speech. Unlike Herder, however, Rousseau insists that language arose from the passions, not from reason (or reflection/Besonnenheit.) Chapter III of Rousseau's Essay, entitled “That the first languages must have been figurative" begins as follows:

As the first motives that made man speak were the passions, his first expressions were Tropes. Figurative language was the first to arise, proper meaning was found last. Things were not called by their true name until they were seen in their genuine form. At first, only poetry was spoken. Only long afterward did anyone take it into his head to reason. ${ }^{58}$

The first language was not, as the rationalists suppose, that of "Geometers" but that of "Poets." Here the differences between Rousseau and Herder become still clearer: where the latter insists that the human soul invents language by isolating a single, defining characteristic which then names the object, the former maintains that words arose through a fundamental mis-apprehension of that object. If both languages are poetic, the dominant trope in Herder's is metonymy (or, more specifically: synecdoche) whilst Rousseau's is based on metaphor. The privileging of one over the other reveals something about the two philosophers' conceptions of identity and difference. Herder is broadly Aristotelian in his belief that each being has its own unique essence which defines it. The sheep is the one that bleats; nothing else bleats, and if it does, then it is behaving unnaturally. In Rousseau's metaphorical conception, by contrast,

58 Rousseau: "Essay" (footnote 13,) p. 107. 
there the formation of the subject in language is based on reciprocity, a mimetic oscillation between Self and Other.

And in the end, Herder cannot suppress this metaphorical transfer either. Despite the essentialism underlying his account, it is an encounter with an animal Other that stimulates the soul to invent language. The sheep bleats; the soul bleats back. Something has been communicated in this exchange, and, as we saw, in the moment even Herder has trouble determining whether it is the sheep or the man who is the one who bleats. In comparing humans to animals, Herder continually reasserts the difference, but he is also forced continually to patrol the borders of the human-animal divide (or the distinction between Nachahmung and Nachäffung) to ensure that monkeys and parrots stay put and that man does not try to imitate them.

But the mimetic impulse- "the nature that culture uses to create second nature, the faculty to copy, imitate, make models, explore difference, yield into and become Other"59-is hard to suppress. Rousseau, musing in his Essay on the "moral" effect of acoustic signs, i.e. of the power that music has "over our hearts," resorts to an animal analogy in order to illustrate his point:

If my cat hears me imitate meowing, I see him immediately attentive, restless, agitated. If he perceives that it is I who is counterfeiting the voice of his fellow, he sits back and relaxes. Why this difference in impression, since there is none in the disturbance of the fibers, and since he himself was at first deceived by it?60

Rousseau takes the cat's reaction to mean that it was initially deceived by his meowing, but that it loses interest once it recognises that it is just its owner fooling around. Let us recall that the beginning of human communication is described in the Essay as the moment in which "one man was recognized by another as a sentient, thinking Being and similar to himself."61 The cat, on hearing the counterfeit meow, interprets it as a marker of similarity, only to be confronted by the unbridgeable abyss of difference between it and its human master. The cat, here, plays the role of Siegfried to Rousseau's Waldvogel. Nor should we overlook the difference in the cat's attitude that Rousseau describes: "attentive, restless, agitated" vs. "he sits back and relaxes." This human meow is somehow disturbing because it threatens, however briefly, to undermine the great divide; but order is restored once the cat/human border is reaffirmed. Rousseau has been "seen in [his] genuine form" and can be "called by [his] true name." The transition from figurative to literal has taken place, but effectively in

59 Michael Taussig: Mimesis and Alterity: A Particular History of the Senses. New York 1993, p. xiii.

60 Rousseau: "Essay" (footnote 13,) p. 136-137.

61 Ibid., p. 103. 
reverse. Rousseau's imitation of his cat, no matter how convincing he may deem it superficially, must nevertheless remain imperfect. It is a counterfeit meow, an imperfect copy that, even in affirming the moral effect of familiar sounds, simultaneously reasserts the inviolability of the human linguistic realm. As a meow, it is a failure.

Likewise, Siegfried's failure is a factor of his perfectibility, which in turn establishes his humanity. Having dispatched his rival, the only thing standing between him and his destiny is his ignorance of fear: the very thing which had permitted him to re-forge the sword and defeat the dragon in the first place. This will be the final stage in his socialisation. For Rousseau too, the trait of perfectibility is intimately bound up with the knowledge and the fear of death: "an animal will never know what it is to die, and the knowledge of death, and of its terrors, is one of man's first acquisitions on moving away from the animal condition." 62 The fear that Siegfried lacks is precisely this peculiarly human, mortal fear, which he cannot learn from an animal. It is not until he discovers Brünhilde at the top of her mountain at the end of Act 3 that he will feel the first pangs of the "feurige Angst" that her aspect inspires in him. In other words, it is not until Siegfried encounters another human being-another mortal, perfectible, linguistic, sentient being-that he is able to feel fear. Moreover, his realisation that "das ist kein Mann!" introduces a notion of difference (or, indeed, of différance) that operates within the boundaries of the species, and hence within the boundaries of language.

But this entrance into language marks a definitive break with Nature, delivering the human over to a world of signification, supplements and imitations. The rest is either silence or noise, and "whatever one may do," Rousseau writes, "noise alone says nothing to the mind, objects have to speak in order to make themselves heard, in every imitation a type of discourse always has to supplement the voice of nature." The voice of nature is unintelligible to man: only through imitation, i.e. by translating it into discourse, can the voice of nature speak. "The musician," he continues, "who wants to render noise with noise is mistaken;"

he knows neither the weakness nor the strength of his art; he judges it without taste, without enlightenment; teach him that he should render noise with song, that if he would make frogs croak, he has to make them sing. ${ }^{63}$

62 Rousseau: Second Discourse (footnote 16,) p. 142. Rousseau thus participates in the long philosophical tradition of positing that animals, because they lack $\lambda$ ó $\gamma \circ$, cannot truly die. For an overview of this tradition, see Akira Mizuta Lippit: Electric Animal: Toward a Rhetoric of Wildlife. Minneapolis 2000, p. 27-73.

63 Rousseau: "Essay" (footnote 13,) p. 136. This is not the only reference to the croaking of frogs in the Essay. In Chapter XIX ("On how music has degenerated,") 
This exhortation is consonant with Wagner's own rejection of "realist" mimicry in art: in order for the Work of Art to speak to "our" hearts, the poet must translate the world into song, and thus transform $\varphi \omega v \eta$ into $\lambda$ ó $\gamma \circ c_{\text {. }}$ Casting a glance back at the score of Siegfried's imitation of the bird, one is immediately struck by the number of different layers of imitation that are at work at once. The sound of Siegfried's reed pipe is rendered, to comic effect, by an English horn (auf dem Theater,) which is instructed to play its notes "grell und unrein, zur Nachahmung eines rohen Rohrinstrumentes"-yet this performance is nevertheless carefully notated so that the performer knows exactly what to play. Indeed, the notes themselves differ only marginally from those played by the clarinet, which is responsible for representing the birdsong. Within the economy of representation, in other words, the interpretation of the notes may vary, but both the English horn and the clarinet are 'speaking' the same 'language'. The animal itself cannot participate, and even if it tried, we would not understand it. ${ }^{64}$

Both Rousseau and Herder insist that of all sensory impressions, sounds have the strongest effect on the human soul. But it is not just any sound: for Rousseau, it is a familiar sound, whereas for Herder it is the specific sound that has been isolated by the human soul from the unintelligible background noise of the world. The animal is always in the world, in a way in which human speech (which is always auf dem Theater) is not. Speech, as the imitation of the animal sound-be it the bleating of a sheep, the meowing of a cat, the song of a forest bird, or the croaking of frogs-superimposes the structure of discourse on the pure voice of nature, and thereby obliterates it. This, then, is the silence of the animal. Reduced to silence, the animal speaks-or rather, sings-not to man, but through him.

Rousseau describes how Europe, "inundated with barbarians and enslaved by the unlearned," lost the perfected harmonious language of the Greeks, which was displaced by the harsh, guttural sounds of the Northern invaders. As proof of this, he notes that "the Emperor Julian compared the speech of the Gauls to the croaking of frogs" (ibid., p. 143.) The emperor's animalising gesture reinscribes the discourse of language within the structure of political power. Here, again, is the flipside of the speech / language dichotomy Rousseau establishes at the beginning of his Essay: by asserting the similarity between this foreign speech and the inarticulate croaking of frogs, the emperor Julian effectively places these outsiders beyond the pale of humanity itself. What separates him from them is not language, but articulate speech as such.

64 Nowhere is this is perhaps more obvious than in Pierre Boulez's classic centenary production of the Ring Cycle at the 1976 Bayreuth Festival, which for the forest bird scene did in fact feature a live bird on stage: in a cage suspended from a tree! 